\title{
Resource use and biophysical constraints of Scottish agriculture
}

\author{
*Silvio Viglia, *Pier Paolo Franzese, *Amalia Zucaro, **Kirsty L. Blackstock, \\ **Keith B. Matthews, *Sergio Ulgiati \\ *Department of Environmental Sciences, Parthenope University of Naples, Italy \\ e-mail: pierpaolo.franzese@uniparthenope.it \\ **Macaulay Land Use Research Institute, Craigiebuckler, Aberdeen, AB15 8QH, U.K.
}

\begin{abstract}
Agriculture is a fundamental sector of economy and society that ensures food supply, classified by the Millennium Ecosystem Assessment among the so-called "provisioning ecosystem services". Due to the increase of food demand worldwide, farmers are shifting more and more towards intensive agriculture. This trend is connected to the unsustainable consumption of natural resources, most often exceeding the carrying capacity of natural ecosystems. In this paper, the resource use and biophysical constraints of Scottish agriculture were investigated at regional and national levels by means of the Emergy Synthesis method. The study focused on two main agroecosystems: 1) the Cairngorms National Park (CNP) and 2) the national agricultural sector of Scotland as a whole. The evolution of the agricultural sector was explored over time (years 1991, 2001, 2007), accounting for local renewable and non-renewable resources as well as imported resources. Performance and sustainability indicators were then calculated with and without including human labor and economic services (money flows). In the year 2007, the Emergy Yield Ratio (EYR) of the Scottish agricultural sector was about $46 \%$ of the same indicator calculated for the CNP (2.65 versus 5.72, respectively). A higher Environmental Loading Ratio (ELR) was calculated for the national sector than for CNP (1.25 versus 1.02, respectively). The Emergy Sustainability Index (ESI) was 2.12 for the national sector and 5.60 for CNP. Such figures were calculated without including the emergy flows supporting labor and services. If the latter are also accounted for, the ESI of the national level and CNP drop by a factor 5.6 and 3.9, respectively. Such variations suggest that larger flows of non-renewable resources strongly affect the environmental performance, increasing the dependence on non-renewable resources supporting the larger economic system in which the agricultural sectors are embedded in.
\end{abstract}

Key words: Scotland, Cairngorms National Park, biophysical accounting, agriculture.

\section{Introduction}

The intensive exploitation of primary production mainly by means of monocultures has a negative effect on biodiversity, water conservation, and soil fertility, putting at risk the future carrying capacity and life support system of many areas of the planet (Brown \& Ulgiati 1999, 2001; MEA 2005). Agriculture is increasingly dependent on large amounts of fertilizers, pesticides, and machinery. In gener$\mathrm{al}$, abandoning traditional practices in favor of more intensive exploitation does not provide additional support to local populations and family farms. Instead, it determines the expulsion of farmers from their land and the concentration of land in the hands of fewer owners and big enterprises, practicing large-scale monocultures and shifting from traditional crops to cash and bioenergy crops. The risks associated to land use change and related social impacts have been underlined by many researchers and international assessments (Pimentel et al. 1973; FAO 2000; Odum 2007; IAASTD 2009) pointing out the need for using technology and science to prevent the decrease of rural population, providing at the same time support to multifunctional agriculture, rural income, and landscape protection.

A crucial step in this framework is the implementation of evaluation methods able to assess the interplay between agricultural processes and natural ecosystems. Very important is also to monitor the performance of agricultural sys- 
tems, identify bottlenecks, and then suggest possible alternatives and improvements. The main goal of this research was the evaluation of the environmental performance and sustainability of the Scottish agricultural system at regional and national scales by using the Emergy Synthesis method, building on previous experiences by Ulgiati et al. (1993, 2008, 2010, 2011), Franzese et al. (2005, 2008, 2009), among others.

\section{Materials and methods}

The resource use and biophysical constraints of the Scottish agricultural system were investigated by using the Emergy Synthesis method (Odum 1996). The resource flows supporting the regional level of the Cairngorms National Park (CNP) and national level of Scotland were evaluated in the years 1991, 2001, and 2007 to assess their environmental performance and sustainability over time. The study of the agricultural system of the CNP is part of a larger investigation on the multifunctional role of protected areas. In fact, while the Scottish agricultural system as such is not constrained by specific environmental protection policies, the activities within the CNP are subject to regulations aimed at preserving the environmental integrity while promoting environmentally friendly activities, among which agriculture and ecotourism.

\subsection{The area of study}

Scotland, located in the north of Britain, is well known for its mountainous landscape rich with forests, rivers, and lakes. Scottish landscape makes difficult to carry out productive activities and as a result of this problem $85 \%$ of Scotland's land is considered a "Less Favoured Area" by the European Union that acknowledges the existence of natural and geographic disadvantages. With a population of about 5,100,000 inhabitants, Scotland has a population density of 65.6 persons $/ \mathrm{km}^{2}$. About 65,000 people are directly employed by the agricultural sector and about 250,000 jobs ( 1 in 10 of all Scottish jobs) derive from this sector. The Cairngorms National Park was started in 2003 as a result of the National Park Act and it is the largest national park in the UK. It covers $3,800 \mathrm{~km}^{2}$ and supports approximately 16,000 resident people as well as important protected habitats and species. National Parks in Scotland are explicitly required to promote sustainable economic and social development. Therefore, they are not "wilderness reserves" but instead they fit the International Union for Conservation of Nature (IUCN) category V (protected landscape). The National Park contains a variety of ecosystems from the sub-arctic Cairngorms plateau through managed moorlands, pastures and forestry to intensively farmed land in the river valleys. Protected for both its bio- diversity and geodiversity, the mosaic of habitats of the Park creates a unique and highly valued landscape. Furthermore, $25 \%$ of species in the UK conservation priority species list is found within the National Park.

\subsection{The Emergy Synthesis method}

Emergy Synthesis is a biophysical accounting method based on the concept of energy quality and focused on the study of natural and human-dominated ecosystems from a "donor-side" point of view: i.e., the evaluation of the work done by the biosphere to generate goods and services (Odum 1996). A more comprehensive explanation of the emergy theory and accounting procedures can be found in Odum (1988, 1994, 1996), Brown and Ulgiati (2004a, b), and Franzese et al. (2009).

A detailed inventory of the main mass, energy and money flows supporting the investigated system is required to perform a sound emergy evaluation. Such evaluations are useful to provide a clear picture of the biophysical support and constraints to the system, included the so-called "free environmental services" (sun, wind, rain, geothermal flow, among others) usually not accounted for by conventional economic and energy accounting. Direct and indirect labor inputs are also accounted for within the emergy accounting as these flows are indirectly supported by additional resource flows within the society.

The following main steps are needed to perform an emergy evaluation oriented to assess the environmental performance and sustainability of the investigated system:

1. Identification of the spatial and temporal boundaries of the investigated systems. The spatial scales of the two systems (regional and national levels) were chosen corresponding to the administrative boundary of the investigated systems while the time scale was one year for both levels.

2. Modelling of the investigated systems by means of a symbolic energy language. A system diagram was drawn, including the main system's components and their interactions to each other and with the surrounding environment.

3 . Inventory of the main inputs to the investigated systems (mass, energy and money flows).

4. Calculation of the emergy flows (seJ) by means of appropriate conversion factors (the so-called UEVs, Unit Emergy Values). Emergy Synthesis includes in its conversion coefficients also the resources provided for free by nature (sun, rain, wind, deep heat, topsoil, etc.). This means that the time and spatial scales of indirect input flows are expanded from the local scale to the scale of biosphere.

5. Calculation of the total emergy used by the systems.

6. Calculation of emergy intensity values for the generated products and emergy-based indicators to describe the system's performance and sustainability.

7. Final interpretation of results. 


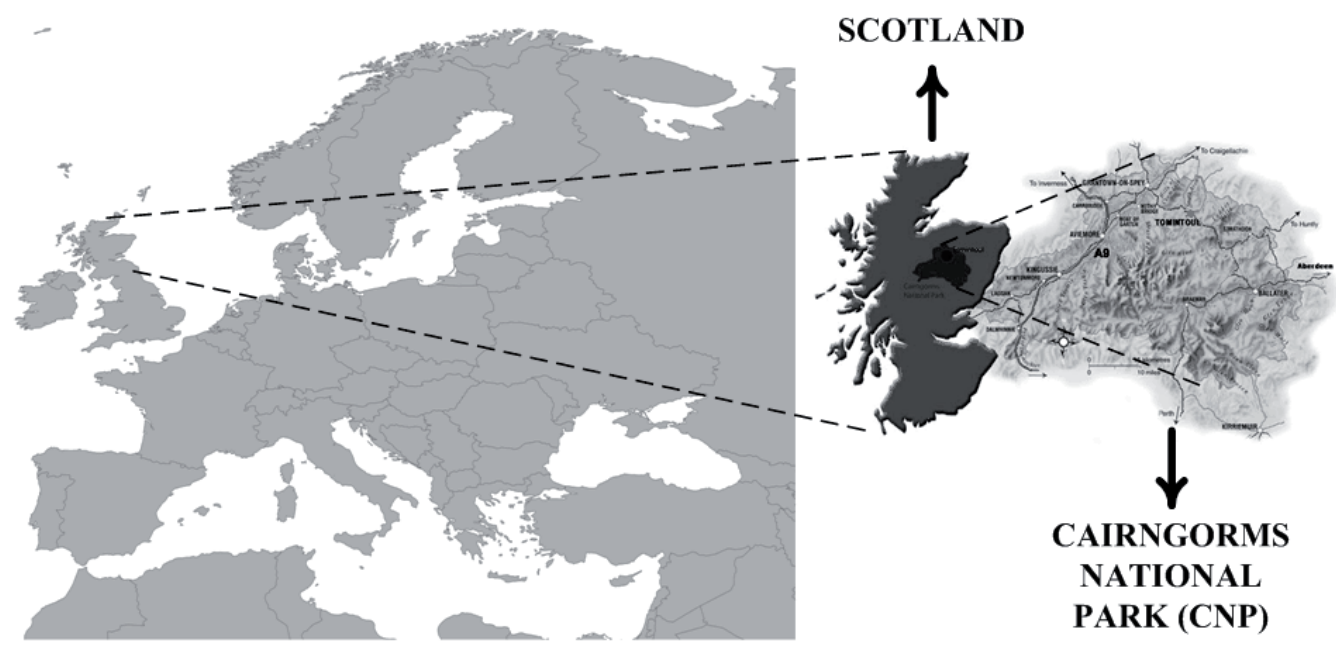

Figure 1. Cairngorms National Park (CNP): geographic location

\section{Results and discussion}

The system diagram of the Cairngorms National Park is shown in Figure 2. In such diagram, three main sub-systems (wilderness, forestry, and agriculture) are directly supported by renewable resources. The renewable flows (sun, rain, wind, geothermal), aggregated on the left of the diagram, support the investigated system directly (wilderness, forestry, and agricultural production) and indirectly (agricultural, forestry, and industrial products). In addition to renewable flows, several human-driven emergy flows imported from the main economy (fossil fuels, fertilizers, electricity, goods, machinery, and labor) support the production patterns of the regional agroecosystem. These flows are shown as inflowing from the top of the diagram (Fig. 2). The people living in the Park receive goods both from internal and external sectors, through commercial and transport infrastructures (assets). Tourists visiting the Cairngorms National Park (CNP) interact with local assets and productive activities, enjoying local products, environmental and recreation services. Finally, when they leave the Park, they are also enriched with a deeper understanding of the environmental, economic, and social aspects of the area. The economic budget of the region is mainly composed by income related to production activities (goods exported) and contribution from external investments and subsidies. Tourists also provide an additional income used to imported goods and raw resources from outside the system. Money flows, drawn by means of dotted lines, are shown as entering from the right side of the diagram and flowing out as payments for services associated to imports. It is important to note that the money paid for resources import only refers to the services associated to such resources. Services measure the indirect labor invested outside of the investigated system to extract and process the raw materials and make processed resources available to the production process (money is not paid to nature for its free resources, but always paid to support direct and indirect labor). Figure 3 shows the emergy diagram drawn for the agricultural sector of Scotland in the year 2007. As shown in Figure 2, due to lack of disaggregated data for crop and livestock sub-systems, we had to make the assumption that all input flows were used to generate the two outputs: livestock and crops. This is because a fraction of agricultural land was used as pasture, while another fraction was used to produce human food and animal feedstock with crop rotation. The total amount of emergy was divided by the amount of agricultural production, thus generating an average value of UEV for crops; then, the same amount of total emergy was divided by the livestock production to generate an average UEV for livestock.

Table 1 shows the direct resource supply and land use of the agricultural sectors of Scotland and CNP over time (years 1991, 2001, and 2007) while Table 2 shows the generated products of the investigated agroecosystems. From these data it clearly appears that both systems follow a similar trend: the direct labor applied to both agricultural processes decreases over time while becoming more expensive. At the same time, the use of agricultural machinery increases, but it is accompanied by a simultaneous decrease of electricity and fuel use, suggesting higher efficiency in machinery use. Fertilizers decrease from 1991 to 2007 , having a peak in the year 2001, while pesticides and herbicides decline steadily. On the product side, the economic value grows in current price terms, while the to- 


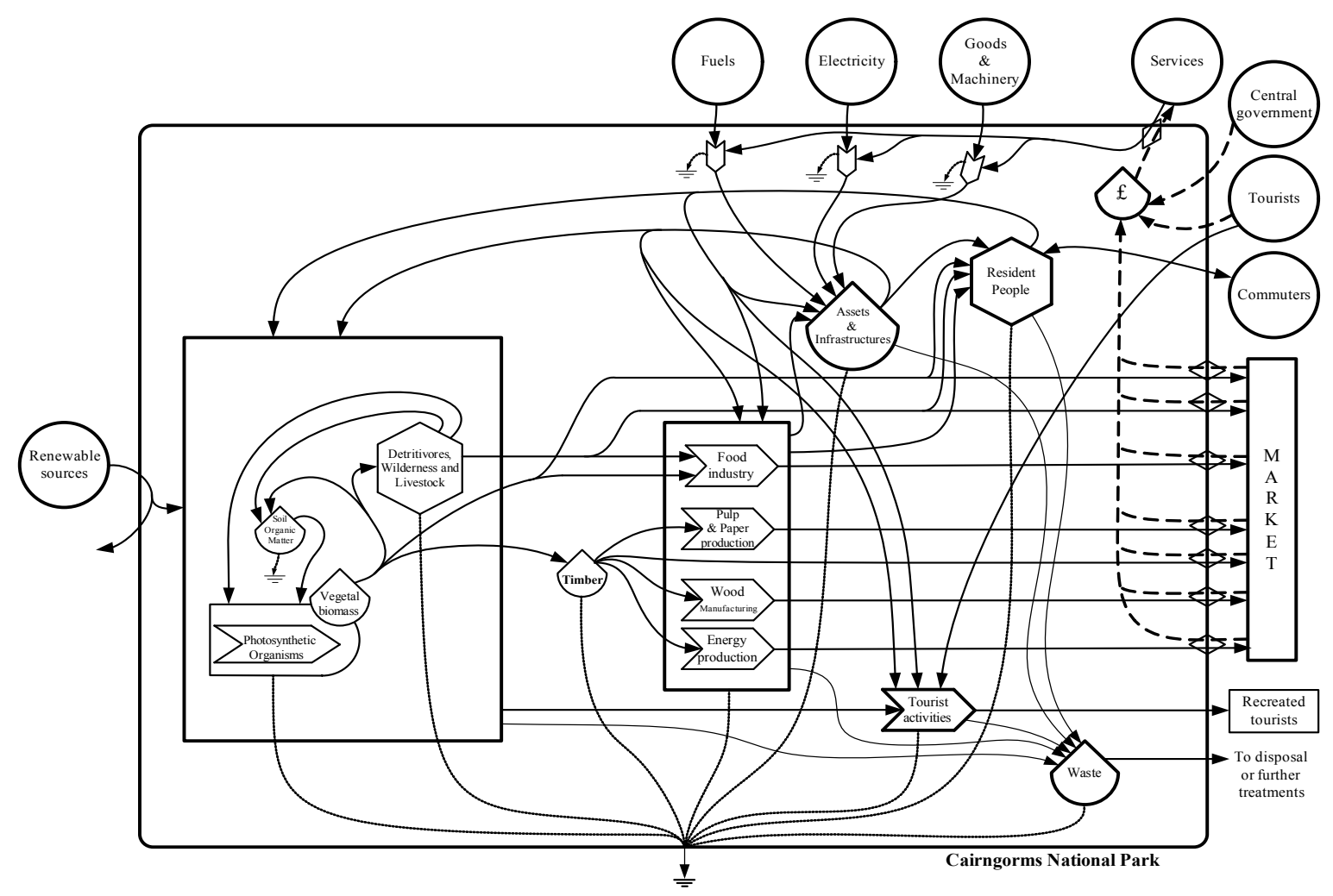

Figure 2. Emergy system diagram of the Cairngorms National Park in the year 2007

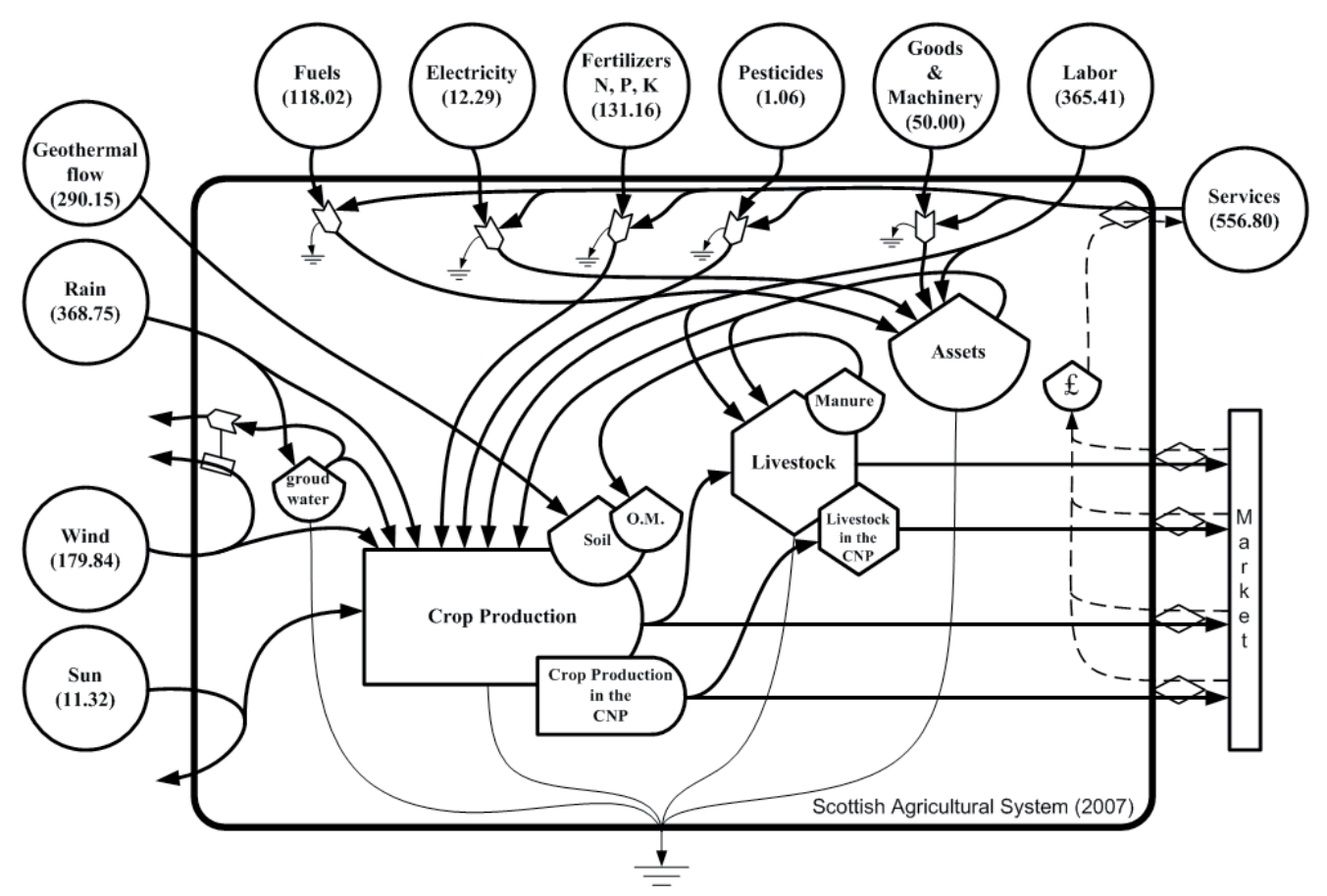

Figure 3. Emergy system diagram of the Scottish agricultural sector. Numbers in bracket are emergy flows (x $\left.10^{18} \mathrm{seJ} / \mathrm{yr}\right)$ associated to each input in the year 2007 
Table 1. Direct supply and land use of the agricultural sectors of Scotland and CNP over time

\begin{tabular}{|c|c|c|c|c|c|c|c|}
\hline \multirow{2}{*}{$\begin{array}{l}\text { Direct supply, land use } \\
\quad \text { (process scale) }\end{array}$} & \multirow{2}{*}{ Unit } & \multicolumn{3}{|c|}{ Scotland } & \multicolumn{3}{|c|}{$\mathrm{CNP}$} \\
\hline & & 1991 & 2001 & 2007 & 1991 & 2001 & 2007 \\
\hline Rainfall & $\mathrm{g} / \mathrm{yr}$ & $5.49 \mathrm{E}+16$ & $5.12 \mathrm{E}+16$ & $6.12 \mathrm{E}+16$ & $1.58 \mathrm{E}+15$ & $1.63 \mathrm{E}+15$ & $1.60 \mathrm{E}+15$ \\
\hline Total Cropped Land & $\mathrm{ha} / \mathrm{yr}$ & $3.92 \mathrm{E}+06$ & $3.92 \mathrm{E}+06$ & $4.15 \mathrm{E}+06$ & $1.79 \mathrm{E}+05$ & $1.79 \mathrm{E}+05$ & $1.79 \mathrm{E}+05$ \\
\hline Fertilizers $\left(\mathrm{N}+\mathrm{PO}_{4}+\mathrm{K}_{2} \mathrm{O}\right)$ & $\mathrm{g} / \mathrm{yr}$ & $3.28 \mathrm{E}+11$ & $4.02 \mathrm{E}+11$ & $2.48 \mathrm{E}+11$ & $4.44 \mathrm{E}+09$ & $4.73 \mathrm{E}+09$ & $3.53 \mathrm{E}+09$ \\
\hline Nitrogen $(\mathrm{N})$ & $\mathrm{g} / \mathrm{yr}$ & $1.95 \mathrm{E}+11$ & $2.27 \mathrm{E}+11$ & $1.38 \mathrm{E}+11$ & $2.61 \mathrm{E}+09$ & $2.84 \mathrm{E}+09$ & $2.03 \mathrm{E}+09$ \\
\hline Phosphate $\left(\mathrm{PO}_{4}\right)$ & $\mathrm{g} / \mathrm{yr}$ & $6.13 \mathrm{E}+10$ & $8.10 \mathrm{E}+10$ & $4.90 \mathrm{E}+10$ & $8.51 \mathrm{E}+08$ & $8.73 \mathrm{E}+08$ & $6.96 \mathrm{E}+08$ \\
\hline Potassium $\left(\mathrm{K}_{2} \mathrm{O}\right)$ & $\mathrm{g} / \mathrm{yr}$ & $7.17 \mathrm{E}+10$ & $9.40 \mathrm{E}+10$ & $6.10 \mathrm{E}+10$ & $9.77 \mathrm{E}+08$ & $1.02 \mathrm{E}+09$ & $8.08 \mathrm{E}+08$ \\
\hline Fungicides & $\mathrm{g} / \mathrm{yr}$ & $1.10 \mathrm{E}+09$ & $6.80 \mathrm{E}+08$ & $7.46 \mathrm{E}+08$ & $2.45 \mathrm{E}+06$ & $1.39 \mathrm{E}+06$ & $1.81 \mathrm{E}+06$ \\
\hline Insecticides & $\mathrm{g} / \mathrm{yr}$ & $5.96 \mathrm{E}+06$ & $3.70 \mathrm{E}+06$ & $2.61 \mathrm{E}+06$ & $3.39 \mathrm{E}+04$ & $2.57 \mathrm{E}+04$ & $2.05 \mathrm{E}+05$ \\
\hline Herbicides & $\mathrm{g} / \mathrm{yr}$ & $9.83 \mathrm{E}+08$ & $7.53 \mathrm{E}+08$ & $6.77 \mathrm{E}+08$ & $1.16 \mathrm{E}+07$ & $5.52 \mathrm{E}+06$ & $2.40 \mathrm{E}+06$ \\
\hline $\begin{array}{l}\text { Growth Regulators, } \\
\text { Molluscicides and Others }\end{array}$ & $\mathrm{g} / \mathrm{yr}$ & $4.63 \mathrm{E}+08$ & $4.63 \mathrm{E}+08$ & $2.01 \mathrm{E}+08$ & $9.57 \mathrm{E}+04$ & $7.11 \mathrm{E}+04$ & $7.28 \mathrm{E}+04$ \\
\hline Electricity & $\mathrm{J} / \mathrm{yr}$ & $9.71 \mathrm{E}+14$ & $5.35 \mathrm{E}+14$ & $4.30 \mathrm{E}+14$ & $8.17 \mathrm{E}+12$ & $4.50 \mathrm{E}+12$ & $3.62 \mathrm{E}+12$ \\
\hline Water for irrigation & $\mathrm{g} / \mathrm{yr}$ & $5.23 \mathrm{E}+12$ & $5.23 \mathrm{E}+12$ & $5.23 \mathrm{E}+12$ & - & - & - \\
\hline Liquid Fuels & $\mathrm{J} / \mathrm{yr}$ & $1.19 \mathrm{E}+16$ & $1.11 \mathrm{E}+16$ & $9.93 \mathrm{E}+15$ & $1.00 \mathrm{E}+14$ & $9.35 \mathrm{E}+13$ & $8.35 \mathrm{E}+13$ \\
\hline Machinery & $\mathrm{g} / \mathrm{yr}$ & $3.30 \mathrm{E}+11$ & $3.78 \mathrm{E}+11$ & $7.19 \mathrm{E}+11$ & $2.78 \mathrm{E}+09$ & $3.18 \mathrm{E}+09$ & $6.05 \mathrm{E}+09$ \\
\hline Direct Labor & $\mathrm{hrs} / \mathrm{yr}$ & $9.15 \mathrm{E}+07$ & $9.16 \mathrm{E}+07$ & $8.45 \mathrm{E}+07$ & $8.66 \mathrm{E}+05$ & $8.67 \mathrm{E}+05$ & $8.00 \mathrm{E}+05$ \\
\hline Direct Labor & $€ / y r$ & $6.06 \mathrm{E}+08$ & $9.24 \mathrm{E}+08$ & $9.35 \mathrm{E}+08$ & $5.73 \mathrm{E}+06$ & $8.74 \mathrm{E}+06$ & $8.85 \mathrm{E}+06$ \\
\hline Indirect Labor (Services) & $€ / y r$ & $1.48 \mathrm{E}+09$ & $1.53 \mathrm{E}+09$ & $1.42 \mathrm{E}+09$ & $7.20 \mathrm{E}+06$ & $6.99 \mathrm{E}+06$ & $9.54 \mathrm{E}+06$ \\
\hline
\end{tabular}

Table 2. Products generated by the agricultural sectors of Scotland and CNP over time

\begin{tabular}{|l|c|c|c|c|c|c|c|}
\hline \multirow{2}{*}{\multicolumn{1}{c|}{ Products }} & \multirow{2}{*}{ Unit } & \multicolumn{3}{c|}{ Scotland } & \multicolumn{3}{c|}{ CNP } \\
\cline { 5 - 8 } & & 1991 & 2001 & 2007 & 1991 & 2001 & 2007 \\
\hline Economic value of crops & $€ / \mathrm{yr}$ & $6.01 \mathrm{E}+08$ & $8.35 \mathrm{E}+08$ & $1.07 \mathrm{E}+09$ & $1.48 \mathrm{E}+06$ & $2.35 \mathrm{E}+06$ & $2.83 \mathrm{E}+06$ \\
\hline Economic value of livestock & $€ / \mathrm{yr}$ & $1.25 \mathrm{E}+09$ & $1.30 \mathrm{E}+09$ & $1.38 \mathrm{E}+09$ & $9.66 \mathrm{E}+06$ & $9.64 \mathrm{E}+06$ & $1.13 \mathrm{E}+07$ \\
\hline Total economic value & $€ / \mathrm{yr}$ & $1.85 \mathrm{E}+09$ & $2.14 \mathrm{E}+09$ & $2.45 \mathrm{E}+09$ & $1.11 \mathrm{E}+07$ & $1.20 \mathrm{E}+07$ & $1.41 \mathrm{E}+07$ \\
\hline Mass of crop production (dry matter) & $\mathrm{g} / \mathrm{yr}$ & $2.85 \mathrm{E}+12$ & $2.85 \mathrm{E}+12$ & $2.92 \mathrm{E}+12$ & $7.51 \mathrm{E}+09$ & $8.36 \mathrm{E}+09$ & $7.61 \mathrm{E}+09$ \\
\hline Mass of livestock production (dry matter) & $\mathrm{g} / \mathrm{yr}$ & $3.04 \mathrm{E}+11$ & $2.86 \mathrm{E}+11$ & $2.89 \mathrm{E}+11$ & $1.17 \mathrm{E}+09$ & $1.00 \mathrm{E}+09$ & $1.06 \mathrm{E}+09$ \\
\hline Total mass (dry matter) & $\mathrm{g} / \mathrm{yr}$ & $3.16 \mathrm{E}+12$ & $3.14 \mathrm{E}+12$ & $3.21 \mathrm{E}+12$ & $8.69 \mathrm{E}+09$ & $9.36 \mathrm{E}+09$ & $8.67 \mathrm{E}+09$ \\
\hline Energy content of crop production & $\mathrm{J} / \mathrm{yr}$ & $3.72 \mathrm{E}+16$ & $3.75 \mathrm{E}+16$ & $3.83 \mathrm{E}+16$ & $1.02 \mathrm{E}+14$ & $1.15 \mathrm{E}+14$ & $1.03 \mathrm{E}+14$ \\
\hline Energy content of livestock production & $\mathrm{J} / \mathrm{yr}$ & $7.81 \mathrm{E}+15$ & $7.45 \mathrm{E}+15$ & $7.65 \mathrm{E}+15$ & $4.54 \mathrm{E}+13$ & $3.87 \mathrm{E}+13$ & $4.06 \mathrm{E}+13$ \\
\hline Total energy content & $\mathrm{J} / \mathrm{yr}$ & $4.50 \mathrm{E}+16$ & $4.50 \mathrm{E}+16$ & $4.59 \mathrm{E}+16$ & $1.48 \mathrm{E}+14$ & $1.53 \mathrm{E}+14$ & $1.44 \mathrm{E}+14$ \\
\hline
\end{tabular}


tal dry mass produced is almost stable as well as the energy content. Table 3. shows the emergy flows supporting the Scottish agricultural sector in the year 2007.

The same emergy evaluation at national level (Table 3) was implemented for the years 1991 and 2001 as well as for the agricultural sector of the Cairngorms National Park for the same years. Finally, performance and sustainability indicators were calculated for both systems.

Table 4 shows the extensive emergy-based indicators calculated for the two systems over time. The total emergy (U) was calculated with and without the emergy associated to labor $(\mathrm{L})$ and services $(\mathrm{S})$. The two values present a significant difference: at national level, labor and services represent about $50 \%$ of the total used emergy (U) while at the level of the National Park they are lower (20-27\%). These figures suggest a highly labor intensive agriculture but also, more likely, a highly subsidized system (money investment for Park protection more than for the value of agricultural products as such).

Tables 5 and 6 list the emergy-based performance indicators calculated for the two agroecosystems. As previously underlined, these indicators refer to the separate crop and livestock products as well as to the agricultural production as a whole, calculated with and without including the emergy flows associated to Labor and Services.

Indicators in Table 6 point out that: 1) the Emergy Yield Ratio (EYR) slightly increases in both systems (increased ability to exploit local resources); 2) the Environmental Loading Ratio (ELR) slightly decreases in both systems (higher reliance on renewable resources); 3) the Emergy Sustainability Index (ESI) increases in both systems. The latter trend is very unusual and suggests the effectiveness of environmental and agricultural policies that seem capable to decrease the use of imported and non-renewable resources and increase the reliance on local renewable resources. When labor and services are accounted for all indicators are affected negatively (Table 5).

Results are better understood in their globality if they are shown in a pictorial way, by means of radar diagrams. To be able to plot data with different orders of magnitude we applied two normalization procedures: 1) normalization with reference to the first year of investigation: all values are divided by the value of the first year of investigation (Figs. 4 and 5); 2) normalization with reference to the total generated impact: for each indicator, the total impact is calculated by adding the values of the two systems, then, to calculate its fraction or percentage, the value of the indicator is divided by the sum of the two (Fig. 6). The larger is the area identified by the diagram, the more intensive is the global impact generated by the system. Figure 4 shows the emergy-based indicators calculated for the agricultural sector at national level. Indicators show a better performance over time, from 1991 to 2007 , with a negative performance in the year 2001. Instead, the same indicators calculated for the CNP show a more stable trend (Fig. 5).

In the year 2007, the Emergy Yield Ratio (EYR) of the Scottish agricultural sector was about $46 \%$ of the same indicator calculated for the CNP (2.65 versus 5.72, respectively). A higher Environmental Loading Ratio (ELR) was calculated for the national sector than for CNP (1.25 versus 1.02, respectively). The Emergy Sustainability Index (ESI) was 2.12 for the national sector and 5.60 for CNP (Table 6). Such figures were calculated without including the emergy flows supporting labor and services. If the latter are also accounted for, the ESI of the national level and CNP drop by a factor 5.6 and 3.9, respectively. Such variations suggest that larger flows of non-renewable resources strongly affect the environmental performance, increasing the dependence on non-renewable resources supporting the larger economic system in which the agricultural sectors are embedded in.

The comparison of the emergy-based indicators between the two investigated systems (Fig. 6) points out a lower performance of the agricultural sector at Park level, affecting the calculated values of $\operatorname{UEV}$ (seJ/€, seJ/g, seJ/J) that resulted higher for the CNP than for the national level. Instead, the other indicators (Empower Density, Emergy Yield Ratio, Environmental Loading Ratio, and Emergy Sustainability Index) resulted higher for the national level, showing the bigger impact of such sector. Finally, the socalled "emergy signature" (Fig. 7) highlights how the share of different resources driving the Scottish National agriculture changed over time. Surprisingly, the local environmental resources still play an important role in comparison to the imported non-renewable (fuels, machinery, fertilizers), unlike other agricultural systems worldwide. Labor and Services also entail a huge emergy cost: however, this is not due to the actual number of hours of labor applied (that is steadily declining), but instead to the standard of living (labor cost, i.e. emergy cost of resources supporting direct and indirect labor). Efforts to decrease the total emergy use of the Country making it more reliant on renewables would translate into less emergy-intensive and more renewable labor and services, in so also improving the performance of agricultural and other productive sectors.

Summarizing, results converge to point out that the whole agricultural sector of Scotland, although performing relatively well compared to other agricultural systems worldwide, is more environmental impacting than the agricultural sector of the CNP. The CNP has a low productivity, while the national sector uses too much non-renewable resources and therefore loads more on the environment. It is promising that the emergy indicators calculated at national level slightly improve over time, and that the same indicators calculated for the CNP remain stable at the already good level achieved thanks to the implementation of strict conservation policies. 
Table 3. Emergy evaluation of the agricultural sector of Scotland in the year 2007

\begin{tabular}{|c|c|c|c|c|c|}
\hline Item & Unit & $\begin{array}{c}\text { Raw } \\
\text { amount }\end{array}$ & $\begin{array}{l}\text { Emergy } \\
\text { Intensity } \\
\text { (seJ/unit) }\end{array}$ & $\begin{array}{l}\text { Ref. for } \\
\text { intensity* }\end{array}$ & $\begin{array}{c}\text { Emergy } \\
\left(\mathrm{x} 10^{18} \mathrm{seJ} / \mathrm{yr}\right)\end{array}$ \\
\hline \multicolumn{6}{|l|}{ Local Renewable Inputs } \\
\hline Solar radiation & $\mathrm{J} / \mathrm{yr}$ & $1.13 \mathrm{E}+20$ & 1 & {$[\mathrm{a}]$} & 11.32 \\
\hline Wind (kinetic energy of wind at surface) & $\mathrm{J} / \mathrm{yr}$ & 7.17E+17 & $2.51 \mathrm{E}+03$ & {$[\mathrm{~b}]$} & 179.84 \\
\hline Rainfall (Chemical Potential) & $\mathrm{J} / \mathrm{yr}$ & $1.21 \mathrm{E}+17$ & $3.05 \mathrm{E}+04$ & {$[\mathrm{~b}]$} & 368.75 \\
\hline Geothermal flow & $\mathrm{J} / \mathrm{yr}$ & $5.04 \mathrm{E}+16$ & $1.20 \mathrm{E}+04$ & {$[\mathrm{~b}]$} & 60.43 \\
\hline \multicolumn{6}{|l|}{ Local Non renewable Inputs } \\
\hline Top soil & $\mathrm{J} / \mathrm{yr}$ & $1.20 \mathrm{E}+16$ & $1.24 \mathrm{E}+05$ & {$[\mathrm{~b}]$} & 149.02 \\
\hline \multicolumn{6}{|l|}{ Inputs Imported from outside } \\
\hline Diesel fuel & $\mathrm{J} / \mathrm{yr}$ & $9.77 \mathrm{E}+15$ & $1.11 \mathrm{E}+05$ & {$[\mathrm{~b}]$} & 108.07 \\
\hline Lubricants & $\mathrm{J} / \mathrm{yr}$ & $1.55 \mathrm{E}+14$ & $1.11 \mathrm{E}+05$ & {$[\mathrm{~b}]$} & 1.72 \\
\hline Natural Gas & $\mathrm{J} / \mathrm{yr}$ & $1.02 \mathrm{E}+15$ & $8.05 \mathrm{E}+04$ & {$[\mathrm{~b}]$} & 8.23 \\
\hline Electricity & $\mathrm{J} / \mathrm{yr}$ & $4.30 \mathrm{E}+14$ & $2.86 \mathrm{E}+05$ & {$[\mathrm{c}]$} & 12.29 \\
\hline Water for irrigation & $\mathrm{g} / \mathrm{yr}$ & $5.23 \mathrm{E}+12$ & $7.61 \mathrm{E}+05$ & {$[\mathrm{~d}]$} & 0.40 \\
\hline \multicolumn{6}{|l|}{ Fertilizers } \\
\hline Nitrogen $(N)$ & $\mathrm{g} / \mathrm{yr}$ & $1.38 \mathrm{E}+11$ & $6.37 \mathrm{E}+09$ & {$[\mathrm{~b}]$} & 87.89 \\
\hline Phosphate $\left(\mathrm{PO}_{4}\right)$ & $\mathrm{g} / \mathrm{yr}$ & $4.90 \mathrm{E}+10$ & $6.54 \mathrm{E}+09$ & {$[\mathrm{~b}]$} & 32.03 \\
\hline Potassium $\left(\mathrm{K}_{2} \mathrm{O}\right)$ & $\mathrm{g} / \mathrm{yr}$ & $6.10 \mathrm{E}+10$ & $1.84 \mathrm{E}+09$ & {$[\mathrm{~b}]$} & 11.25 \\
\hline Fungicide & $\mathrm{g} / \mathrm{yr}$ & $7.46 \mathrm{E}+08$ & $5.08 \mathrm{E}+09$ & {$[\mathrm{e}]$} & 0.38 \\
\hline Insecticides & $\mathrm{g} / \mathrm{yr}$ & $2.61 \mathrm{E}+06$ & $4.81 \mathrm{E}+09$ & [e] & 0.001 \\
\hline Herbicides & $\mathrm{g} / \mathrm{yr}$ & $6.77 \mathrm{E}+08$ & $8.25 \mathrm{E}+09$ & [e] & 0.56 \\
\hline Growth regulators, Molluscicides and others & $\mathrm{g} / \mathrm{yr}$ & $2.01 \mathrm{E}+08$ & $6.05 \mathrm{E}+09$ & {$[\mathrm{e}]$} & 0.12 \\
\hline \multicolumn{6}{|l|}{ Agricultural machinery } \\
\hline Steel and Iron & $\mathrm{g} / \mathrm{yr}$ & $4.53 \mathrm{E}+10$ & $5.31 \mathrm{E}+09$ & {$[\mathrm{f}]$} & 24.07 \\
\hline Aluminium & $\mathrm{g} / \mathrm{yr}$ & $7.74 \mathrm{E}+09$ & $3.25 \mathrm{E}+10$ & {$[\mathrm{~b}]$} & 25.17 \\
\hline Rubber and Plastic & $\mathrm{g} / \mathrm{yr}$ & $5.53 \mathrm{E}+08$ & $3.69 \mathrm{E}+09$ & {$[\mathrm{~b}]$} & 0.20 \\
\hline Copper & $\mathrm{g} / \mathrm{yr}$ & $1.66 \mathrm{E}+09$ & $3.36 \mathrm{E}+09$ & {$[\mathrm{c}]$} & 0.56 \\
\hline Human Labor & $€ / \mathrm{yr}$ & $9.35 \mathrm{E}+08$ & $3.91 \mathrm{E}+12$ & {$[\mathrm{~g}]$} & 365.41 \\
\hline Annual Services in Agricultural Production & $€ / y r$ & $1.42 \mathrm{E}+09$ & $3.91 \mathrm{E}+12$ & {$[\mathrm{~g}]$} & 556.80 \\
\hline TOTAL EMERGY with Labor and Services & & & & & 1752.91 \\
\hline TOTAL EMERGY without Labor and Services & & & & & 830.70 \\
\hline
\end{tabular}

*References for Transformity values: [a] [by definition]; [b] [after Odum 2000]; [c] [Brown \& Ulgiati 2004b]; [d] [after Buenfill A.A. 2000]; [e] [estimated from Biondi et. al. 1989]; [f] [Bargigli \& Ulgiati 2003]; [g] [Gasparatos et al. 2008].

Note: Values of specific emergies and transformities refer to the $15.83 \cdot 10^{24} \mathrm{seJ} / \mathrm{yr}$ biosphere baseline (Odum 2000). All transformities calculated earlier, based on the $9.44 \cdot 10^{24} \mathrm{seJ} / \mathrm{yr}$ baseline, have been multiplied by 1.68 to be update. 
Table 4. Extensive emergy-based indicators of the agricultural sectors of Scotland and CNP over time

\begin{tabular}{|l|c|c|c|c|c|c|c|}
\hline \multirow{2}{*}{ Extensive Indicators } & \multirow{2}{*}{ Unit } & \multicolumn{3}{c|}{ Scotland } & \multicolumn{3}{c|}{ CNP } \\
\cline { 5 - 8 } & & 1991 & 2001 & 2007 & 1991 & 2001 & 2007 \\
\hline Local renewable inputs, R & $\mathrm{seJ} / \mathrm{yr}$ & $3.31 \mathrm{E}+21$ & $3.08 \mathrm{E}+21$ & $3.69 \mathrm{E}+21$ & $9.55 \mathrm{E}+19$ & $9.85 \mathrm{E}+19$ & $9.66 \mathrm{E}+19$ \\
\hline Local non-renewable inputs, N & $\mathrm{seJ} / \mathrm{yr}$ & $1.41 \mathrm{E}+21$ & $1.41 \mathrm{E}+21$ & $1.49 \mathrm{E}+21$ & $6.45 \mathrm{E}+19$ & $6.45 \mathrm{E}+19$ & $6.45 \mathrm{E}+19$ \\
\hline Purchased inputs, F & $\mathrm{seJ} / \mathrm{yr}$ & $3.65 \mathrm{E}+21$ & $3.90 \mathrm{E}+21$ & $3.13 \mathrm{E}+21$ & $3.97 \mathrm{E}+19$ & $4.03 \mathrm{E}+19$ & $3.42 \mathrm{E}+19$ \\
\hline Direct Labor, L & $\mathrm{seJ} / \mathrm{yr}$ & $2.37 \mathrm{E}+21$ & $3.61 \mathrm{E}+21$ & $3.65 \mathrm{E}+21$ & $2.24 \mathrm{E}+19$ & $3.42 \mathrm{E}+19$ & $3.46 \mathrm{E}+19$ \\
\hline Services (indirect labor), S & $\mathrm{seJ} / \mathrm{yr}$ & $5.80 \mathrm{E}+21$ & $5.98 \mathrm{E}+21$ & $5.57 \mathrm{E}+21$ & $2.82 \mathrm{E}+19$ & $2.73 \mathrm{E}+19$ & $3.73 \mathrm{E}+19$ \\
\hline $\begin{array}{l}\text { Total emergy inputs with L\&S; } \\
\text { U = (R+N+F+L+S) }\end{array}$ & $\mathrm{seJ} / \mathrm{yr}$ & $1.65 \mathrm{E}+22$ & $1.80 \mathrm{E}+22$ & $1.75 \mathrm{E}+22$ & $2.50 \mathrm{E}+20$ & $2.65 \mathrm{E}+20$ & $2.67 \mathrm{E}+20$ \\
\hline $\begin{array}{l}\text { Total emergy inputs without L\&S; } \\
\text { U = (R+N+F) }\end{array}$ & $\mathrm{seJ} / \mathrm{yr}$ & $8.36 \mathrm{E}+21$ & $8.39 \mathrm{E}+21$ & $8.31 \mathrm{E}+21$ & $2.00 \mathrm{E}+20$ & $2.03 \mathrm{E}+20$ & $1.95 \mathrm{E}+20$ \\
\hline
\end{tabular}

Table 5. Intensive emergy-based indicators of the agricultural sectors of Scotland and CNP (with Labor and Services)

\begin{tabular}{|c|c|c|c|c|c|c|c|}
\hline \multirow[b]{2}{*}{ Intensive Indicators with Labor and Services } & \multirow[b]{2}{*}{ Unit } & \multicolumn{3}{|c|}{ Scotland } & \multicolumn{3}{|c|}{$\mathrm{CNP}$} \\
\hline & & 1991 & 2001 & 2007 & 1991 & 2001 & 2007 \\
\hline \multicolumn{8}{|l|}{ CROPS } \\
\hline Emergy per unit of economic value & $\mathrm{seJ} / €$ & $2.75 \mathrm{E}+13$ & $2.15 \mathrm{E}+13$ & $1.64 \mathrm{E}+13$ & $1.69 \mathrm{E}+14$ & $1.12 \mathrm{E}+14$ & $9.43 \mathrm{E}+13$ \\
\hline Specific Emergy per unit of dry matter & $\mathrm{seJ} / \mathrm{g}$ & $5.79 \mathrm{E}+09$ & $6.31 \mathrm{E}+09$ & $6.00 \mathrm{E}+09$ & $3.33 \mathrm{E}+10$ & $3.17 \mathrm{E}+10$ & $3.51 \mathrm{E}+10$ \\
\hline Solar Transformity & $\mathrm{seJ} / \mathrm{J}$ & $4.45 \mathrm{E}+05$ & $4.80 \mathrm{E}+05$ & $4.58 \mathrm{E}+05$ & $2.45 \mathrm{E}+06$ & $2.31 \mathrm{E}+06$ & $2.59 \mathrm{E}+06$ \\
\hline \multicolumn{8}{|l|}{ LIVESTOCK } \\
\hline Emergy per unit of economic value & $\mathrm{seJ} / €$ & $1.32 \mathrm{E}+13$ & $1.38 \mathrm{E}+13$ & $1.27 \mathrm{E}+13$ & $2.59 \mathrm{E}+13$ & $2.75 \mathrm{E}+13$ & $2.37 \mathrm{E}+13$ \\
\hline Specific Emergy per unit of dry matter & $\mathrm{seJ} / \mathrm{g}$ & $5.44 \mathrm{E}+10$ & $6.30 \mathrm{E}+10$ & $6.07 \mathrm{E}+10$ & $2.13 \mathrm{E}+11$ & $2.64 \mathrm{E}+11$ & $2.53 \mathrm{E}+11$ \\
\hline Solar Transformity & $\mathrm{seJ} / \mathrm{J}$ & $2.12 \mathrm{E}+06$ & $2.42 \mathrm{E}+06$ & $2.29 \mathrm{E}+06$ & $5.51 \mathrm{E}+06$ & $6.85 \mathrm{E}+06$ & $6.58 \mathrm{E}+06$ \\
\hline \multicolumn{8}{|l|}{ WHOLE SYSTEM } \\
\hline Emergy per unit of economic value & $\mathrm{seJ} / €$ & $8.93 \mathrm{E}+12$ & $8.41 \mathrm{E}+12$ & $7.15 \mathrm{E}+12$ & $2.25 \mathrm{E}+13$ & $2.21 \mathrm{E}+13$ & $1.89 \mathrm{E}+13$ \\
\hline Specific Emergy per unit of dry matter & $\mathrm{seJ} / \mathrm{g}$ & $5.24 \mathrm{E}+09$ & $5.74 \mathrm{E}+09$ & $5.46 \mathrm{E}+09$ & $2.88 \mathrm{E}+10$ & $2.83 \mathrm{E}+10$ & $3.08 \mathrm{E}+10$ \\
\hline Solar Transformity & $\mathrm{seJ} / \mathrm{J}$ & $3.68 \mathrm{E}+05$ & $4.00 \mathrm{E}+05$ & $3.82 \mathrm{E}+05$ & $1.70 \mathrm{E}+06$ & $1.73 \mathrm{E}+06$ & $1.86 \mathrm{E}+06$ \\
\hline Empower density & $\mathrm{seJ} / \mathrm{ha}$ & $4.22 \mathrm{E}+15$ & $4.59 \mathrm{E}+15$ & $4.23 \mathrm{E}+15$ & $1.39 \mathrm{E}+15$ & $1.48 \mathrm{E}+15$ & $1.49 \mathrm{E}+15$ \\
\hline $\mathrm{EYR}=\mathrm{U} /(\mathrm{F}+\mathrm{L}+\mathrm{S})$ & & 1.40 & 1.33 & 1.42 & 2.77 & 2.60 & 2.52 \\
\hline $\mathrm{ELR}=(\mathrm{N}+\mathrm{F}+\mathrm{L}+\mathrm{S}) /(\mathrm{R})$ & & 4.00 & 4.83 & 3.75 & 1.62 & 1.69 & 1.77 \\
\hline$\% \mathrm{REN}=1 /(1+\mathrm{ELR})$ & & 0.20 & 0.17 & 0.21 & 0.38 & 0.37 & 0.36 \\
\hline $\mathrm{ESI}=\mathrm{EYR} / \mathrm{ELR}$ & & 0.35 & 0.28 & 0.38 & 1.71 & 1.54 & 1.43 \\
\hline
\end{tabular}


Table 6. Intensive emergy indicators of the agricultural sectors of Scotland and CNP (without Labor and Services)

\begin{tabular}{|c|c|c|c|c|c|c|c|}
\hline \multirow{2}{*}{$\begin{array}{c}\text { Intensive Indicators without Labor and } \\
\text { Services }\end{array}$} & \multirow{2}{*}{ Unit } & \multicolumn{3}{|c|}{ Scotland } & \multicolumn{3}{|c|}{$\mathrm{CNP}$} \\
\hline & & 1991 & 2001 & 2007 & 1991 & 2001 & 2007 \\
\hline \multicolumn{8}{|l|}{ CROPS } \\
\hline Emergy per unit of economic value & $\mathrm{seJ} / €$ & $1.39 \mathrm{E}+13$ & $1.01 \mathrm{E}+13$ & $7.76 \mathrm{E}+12$ & $1.35 \mathrm{E}+14$ & $8.64 \mathrm{E}+13$ & $6.89 \mathrm{E}+13$ \\
\hline Specific Emergy per unit of dry matter & $\mathrm{seJ} / \mathrm{g}$ & $2.93 \mathrm{E}+09$ & $2.94 \mathrm{E}+09$ & $2.84 \mathrm{E}+09$ & $2.66 \mathrm{E}+10$ & $2.43 \mathrm{E}+10$ & $2.57 \mathrm{E}+10$ \\
\hline Solar Transformity & $\mathrm{seJ} / \mathrm{J}$ & $2.25 \mathrm{E}+05$ & $2.24 \mathrm{E}+05$ & $2.17 \mathrm{E}+05$ & $1.96 \mathrm{E}+06$ & $1.77 \mathrm{E}+06$ & $1.89 \mathrm{E}+06$ \\
\hline \multicolumn{8}{|l|}{ LIVESTOCK } \\
\hline Emergy per unit of economic value & $\mathrm{seJ} / €$ & $6.69 \mathrm{E}+12$ & $6.44 \mathrm{E}+12$ & $6.02 \mathrm{E}+12$ & $2.07 \mathrm{E}+13$ & $2.11 \mathrm{E}+13$ & $1.73 \mathrm{E}+13$ \\
\hline Specific Emergy per unit of dry matter & $\mathrm{seJ} / \mathrm{g}$ & $2.75 \mathrm{E}+10$ & $2.94 \mathrm{E}+10$ & $2.88 \mathrm{E}+10$ & $1.70 \mathrm{E}+11$ & $2.03 \mathrm{E}+11$ & $1.85 \mathrm{E}+11$ \\
\hline Solar Transformity & $\mathrm{seJ} / \mathrm{J}$ & $1.07 \mathrm{E}+06$ & $1.13 \mathrm{E}+06$ & $1.09 \mathrm{E}+06$ & $4.39 \mathrm{E}+06$ & $5.26 \mathrm{E}+06$ & $4.81 \mathrm{E}+06$ \\
\hline \multicolumn{8}{|l|}{ WHOLE SYSTEM } \\
\hline Emergy per unit of economic value & $\mathrm{seJ} / €$ & $4.52 \mathrm{E}+12$ & $3.93 \mathrm{E}+12$ & $3.39 \mathrm{E}+12$ & $1.79 \mathrm{E}+13$ & $1.69 \mathrm{E}+13$ & $1.38 \mathrm{E}+13$ \\
\hline Specific Emergy per unit of dry matter & $\mathrm{seJ} / \mathrm{g}$ & $2.65 \mathrm{E}+09$ & $2.68 \mathrm{E}+09$ & $2.59 \mathrm{E}+09$ & $2.30 \mathrm{E}+10$ & $2.17 \mathrm{E}+10$ & $2.25 \mathrm{E}+10$ \\
\hline Solar Transformity & $\mathrm{seJ} / \mathrm{J}$ & $1.86 \mathrm{E}+05$ & $1.87 \mathrm{E}+05$ & $1.81 \mathrm{E}+05$ & $1.35 \mathrm{E}+06$ & $1.33 \mathrm{E}+06$ & $1.36 \mathrm{E}+06$ \\
\hline Empower density & $\mathrm{seJ} / \mathrm{ha}$ & $2.14 \mathrm{E}+15$ & $2.14 \mathrm{E}+15$ & $2.00 \mathrm{E}+15$ & $1.11 \mathrm{E}+15$ & $1.13 \mathrm{E}+15$ & $1.09 \mathrm{E}+15$ \\
\hline $\mathrm{EYR}=\mathrm{U} / \mathrm{F}$ & & 2.29 & 2.15 & 2.65 & 5.03 & 5.04 & 5.72 \\
\hline $\mathrm{ELR}=(\mathrm{N}+\mathrm{F}) /(\mathrm{R})$ & & 1.53 & 1.72 & 1.25 & 1.09 & 1.06 & 1.02 \\
\hline$\% \mathrm{REN}=1 /(1+\mathrm{ELR})$ & & 0.40 & 0.37 & 0.44 & 0.48 & 0.48 & 0.49 \\
\hline $\mathrm{ESI}=\mathrm{EYR} / \mathrm{ELR}$ & & 1.50 & 1.25 & 2.12 & 4.61 & 4.74 & 5.60 \\
\hline
\end{tabular}

Figure 4. Emergy-based indicators of the agricultural sector of Scotland over time. Values normalized from Table 5

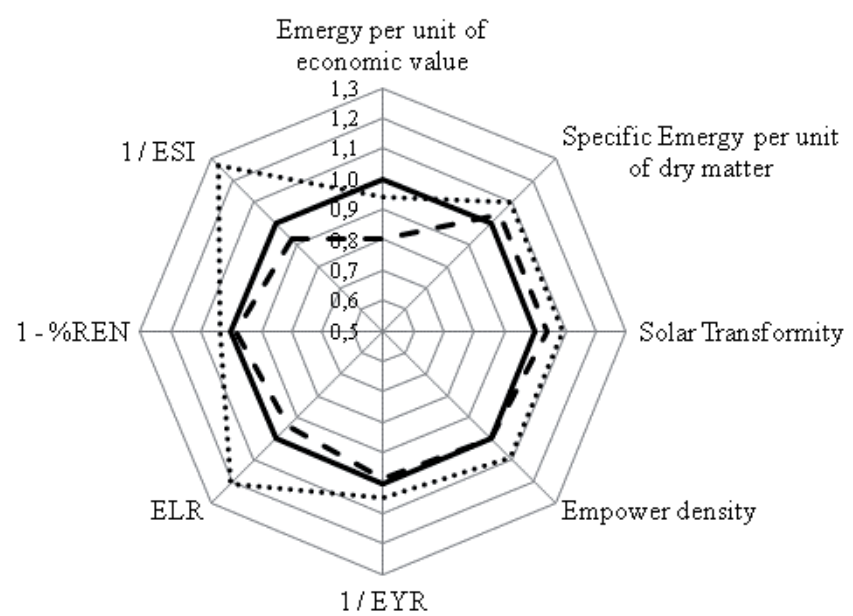

$-1991$

...... 2001 

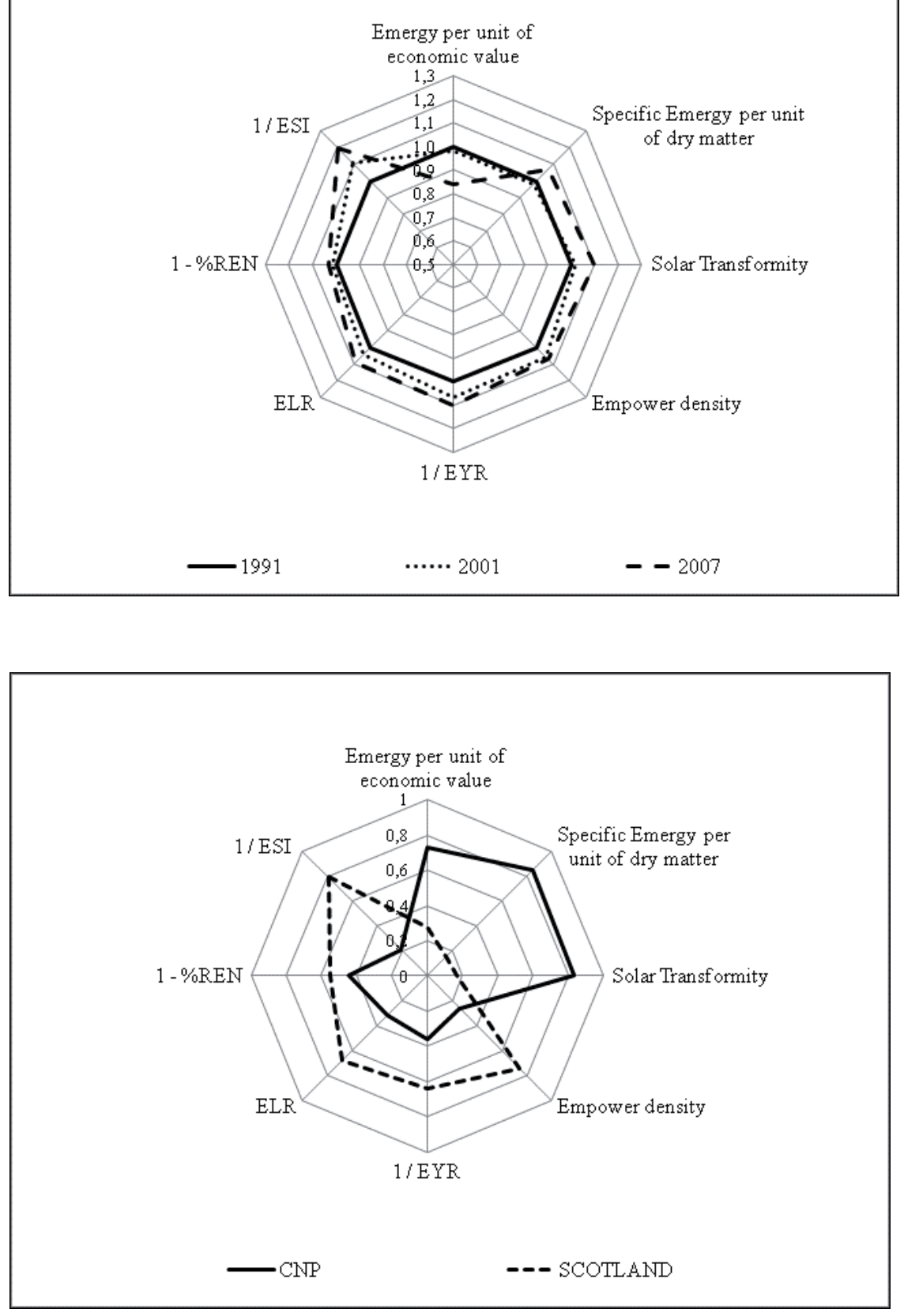

Figure 5. Emergy-based indicators of the agricultural sector of the Cairngorms National Park over time. Values normalized from Table 5
Figure 6. Comparison of emergy-based indicators referring to the agricultural sectors of Scotland and CNP in the year 2007. Values normalized from Table 5
Results also raise an important aspect related to the interplay between the need for high productivity in support of a large population (Scotland, 65.6 persons $/ \mathrm{km} 2$ ) traded for higher environmental load and enforced environmental protection in a system (the CNP) that is hardly capable of supporting 4 persons $/ \mathrm{km}^{2}$. Policies that are concerned about both standard of living and environmental protection need to address efficient and effective use of resources (doing more with less) and decreasing use of non-renewable and imported resources (increased reliance on local sources). The latter aspect requires that local resources are both conserved (clean environment, traditions, food quality) and usefully exploited within a multifunctional framework based on additional income from diversification of activities as well as increased use and reuse of residues. It is not a given that such strategies are feasible to the extent that is required to keep the same standard of living and improve environmental care. It is also not a given that Scottish population may accept a lower standard of living (in terms of resource use) to allow for the same standard 


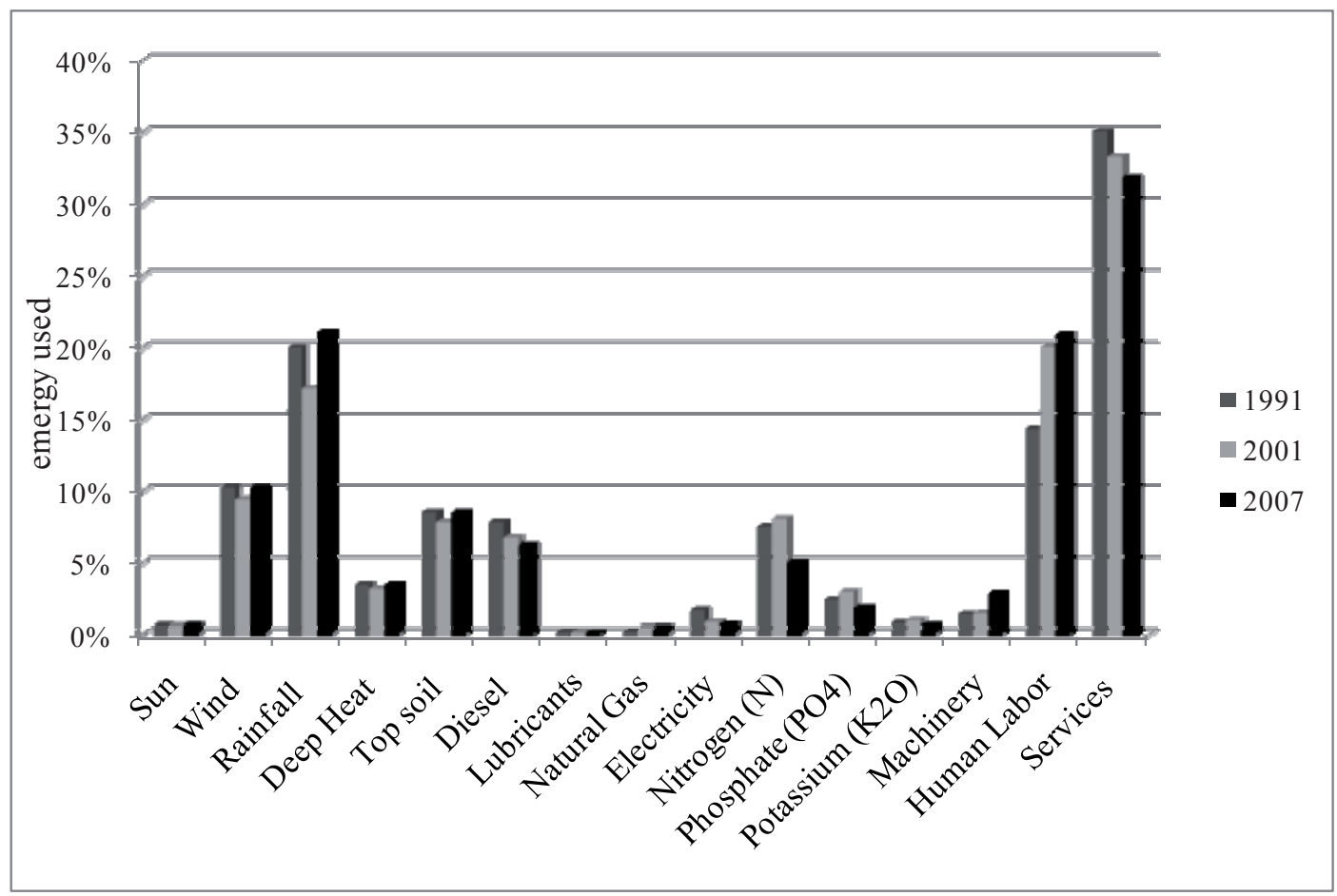

Figure 7. Emergy signature of the agricultural sector of Scotland over time

of environmental protection performed within the CNP. Finally, it is still to be understood if an optimum share of economic development and environmental protection can be identified and, if so, implemented through top-down policies. This is why policy enforcement and performance monitoring must both be implemented to allow deeper understanding and sound actions.

\section{Conclusion}

Results point out a global environmentally sound performance of the Scottish agriculture and an even better performance of agricultural activities in the Cairngorms National Park. However, the comparison between the two systems identifies a trade-off between increased economic production and environmental protection. Reliance on local renewable resources is unlikely to allow high yields as energy intensive production still does. On the other hand, increased population and standard of living call for production activities much beyond the carrying capacity of the region. Policies that improve the multi-functionality of production activities and support the "doing more with less" can help, but they seem far from being able to fill the existing gap between expectations for economic improvement and awareness of the need for environmental integrity.
Moreover, the large fraction of emergy provided as labor and services in both the investigated systems suggests that the global performance of the Scottish economy, based on large flows of non-renewable resources, heavily affects the dynamics of the agricultural sector. In fact, labor and services rely on the non-renewable emergy sources that support the main economy. Such a finding points out the need for an accurate exploration of the context in which the investigated process is embedded in and suggests that efforts for the improvement of the performance of a productive sector are unlikely to be successful without a simultaneous effort for the improvement of the larger surrounding economic system. Saving resources in a given sector with the hope that they can be reinvested somewhere else to keep pushing the standard of living to a even higher level of resource consumption may translate into a crude awakening. When the lifestyle goes up, it affects the economic and emergy cost of labor, in so making the single productive sectors less effective and sustainable. Some investors may decide to outsource the production, some others may decide to decrease labor by increasing machinery (until oil price allows), and others simply may go out of business. Instead, if the standard of living is reoriented toward lower consumer habits and higher community values, then all the sectorial performance indicators may benefit from the lower large-scale resource use. 
The application of the Emergy Synthesis method allows monitoring the use of different kind of resources over time, also taking into account their different quality. In so doing, aspects that are most often disregarded in conventional economic and energy analyses are highlighted and become the basis of more environmentally sound policies. In particular, it becomes possible to identify trade-offs between intensity of resource use, standard of living, and environmental integrity that are linked to each other by internal loops and synergies, and would otherwise remain hidden and not accounted for.

\section{Acknowledgement}

The Authors gratefully acknowledge the financial support received from the European Commission within the 7th Framework Program, Project no.217213, SMILE - Synergies in Multi-scale Inter-Linkages of Eco-social systems. Socioeconomic Sciences and Humanities (SSH) Collaborative Project FP7-SSH-2007-1.

\section{References}

Bargigli S. \& Ulgiati S., 2003, Emergy and Life-Cycle Assessment of Steel Production in Europe, [in:] M. T. Brown, H. T. Odum, D. Tilley, S. Ulgiati (eds.), EMERGY SYNTHESIS 2. Theory and Applications of the Emergy Methodology, H. T. Odum Center for Environmental Policy, University of Florida, Gainesville, Florida, USA, September 2001.

Biondi P., Panaro V. \& Pellizzi G., 1989, Le Richieste di Energia del Sistema Agricolo Italiano, CNR, Consiglio Nazionale delle Ricerche, Progetto Finalizzato Energetica, Sottoprogetto Biomasse ed Agricoltura, Report LB-20, Roma, Italia.

Brown M. T. \& Ulgiati S., 1999, Emergy evaluation of the biosphere and natural capital, Ambio 28: 486-493.

Brown M. T. \& Ulgiati S., 2001, A Quantitative Method for Determining Carrying Capacity For Economic Investments, International Journal of Population and Environment 22(5): 471-501.

Brown M. T. \& Ulgiati S., 2004a, Energy Quality, Emergy, and Transformity: H. T. Odum's contribution to quantifying and understanding systems, Ecological Modelling 178: 201-213.

Brown M. T. \& Ulgiati S., 2004b, Emergy Analysis and Environmental Accounting, [in:] Encyclopedia of Energy, Elsevier, Oxford, UK: 329-354.

Buenfill A. A., 2000, Sustainable Use of Potable Water in Florida: an Emergy Analysis of Water Supply and Treatment Alternatives, [in:] M. T. Brown, S. BrandtWilliams, D. Tilley, S. Ulgiati (eds.), EMERGY SYN-
THESIS. Theory and Applications of the Emergy Methodology, H. T. Odum Center for Environmental Policy, University of Florida, Gainesville, Florida, USA, September 1999.

FAO, 2000, Food and Agriculture Organization of the United Nations, Overview, 84.

Franzese P. P., Russo G. F. \& Ulgiati S., 2005, Geographical information systems and emergy analysis method to evaluate resource and energy flows in waste management systems, Proceedings of the VII Polish Conference on Energy and Ecology, 19-21 October 2005, Toruń, Poland: 353-367.

Franzese P. P., Russo G. F. \& Ulgiati S., 2008, Modeling the interplay of environment, economy and resources in marine protected areas. a case study in Southern Italy, Ecological Questions 10: 91-97.

Franzese P. P., Rydberg T., Russo G. F. \& Ulgiati S., 2009, Sustainable biomass production: a comparison between Gross Energy Requirement and Emergy Synthesis methods, Ecological Indicators 9: 959-970.

Gasparatos A., El-Haram M. \& Horner M., 2008, Assessing the sustainability of the UK society using thermodynamic concepts: Part 1, Renewable and Sustainable Energy Reviews 13: 1074-1081.

IAASTD, 2009, International Assessment of Agricultural Knowledge, Science and Technology for Development, Agriculture at a Crossroads Island Press, Washington, DC.

MEA, 2005, Millennium Ecosystem Assessment, Ecosystems and Human Well-being: Synthesis, Island Press, Washington, DC.

Odum H. T., 1988, Self organization, transformity and information, Science 242: 1132-1139.

Odum H. T., 1994, Ecological and General Systems, University Press of Colorado, USA.

Odum H. T., 1996, Environmental Accounting: Emergy and Environmental Decision Making, John Wiley and Sons, New York.

Odum H. T., 2000, Handbook of Emergy Evaluation Folio 2: Emergy of Global Processes, Centre for Environmental Policy, University of Florida, Gainesville.

Odum H. T., 2007, Environment, Power and Society for the Twenty-First Century: The Hierarchy of Energy, Columbia University Press, USA.

Pimentel D., Hurd L. E., Bellotti A. C., Forster M. J., Oka I. N., Sholes O. D. \& Whitman R. J., 1973, Food Production and the Energy Crisis, Science 182: 443-449.

Ulgiati S., Odum H. T. \& Bastianoni S., 1993, Emergy Analysis of Italian Agriculture System. The role of Energy Quality and Environmental Inputs, [in:] L. Bonati, U. Cosentino, M. Lasagni, G. Moro, D. Pitea, A. Schiraldi (eds.) Trends in Ecological Physical Chemistry, Elsevier Science Publishers, Amsterdam, the Netherlands: 187-215. 
Ulgiati S., Zucaro A. \& Franzese P. P., 2008, Matter, Energy and Emergy Assessment in the agricultural sectors of the Campania region. Constrains, bottlenecks and perspectives, [in:] H. Schnitzer, S. Ulgiati (eds.) 6th Biennial International Workshop Advances in Energy Studies, Towards a holistic approach based on science and humanity, Graz University of Technology, Austria: $550-560$.
Ulgiati S., Zucaro A. \& Franzese P. P., 2010, Shared Wealth or Nobody's Land? The Worth of Natural Capital and Ecosystem Services, Ecological Economics, in press.

Ulgiati S., Ascione M., Bargigli S., Cherubini F., Franzese P. P., Viglia S. \& Zucaro A., 2011, Material, Energy and Environmental Performance of Technological and Social Systems under a Life Cycle Assessment Perspective, Ecological Modelling 222:176-189. 